\title{
The role of local embeddedness and non-local knowledge in entrepreneurial activity
}

\author{
Mikhail Martynovich (10
}

Accepted: 11 April 2017 /Published online: 4 May 2017

(C) The Author(s) 2017. This article is an open access publication

\begin{abstract}
The article investigates whether the history of individuals' spatial relocation has an impact on their propensity to perform an entrepreneurial entry and post-entry performance of firms they start. By looking at entrepreneurs in the IT services sector in Swedish non-core regions between 1991 and 2010, the article investigates the interaction between individuals' embeddedness in local networks and their exposure to external knowledge accumulation opportunities across different geographical settings, as well as its impact on their entrepreneurial activities. The results of the analysis suggest that individuals with broad spatial relocation histories are more likely to start IT firms in non-core regions, which, in turn, may be expected to survive longer. It is, therefore, claimed that non-local knowledge accumulated through spatial relocation is an important complement to embeddedness in local networks in noncore regions. This complementarity is further related to the evolution of the IT services sector over time.
\end{abstract}

Keywords Entrepreneurship · Mobility - Locational behavior - Spatial biographies · Local embeddedness . Non-local knowledge

\section{JEL classification $\mathrm{J} 61 \cdot \mathrm{L} 26 \cdot \mathrm{L} 86 \cdot \mathrm{M} 13$}

M. Martynovich $(\bowtie)$

Department of Human Geography, Faculty of Social Sciences, Lund University, Sölvegatan 10, Kulturgeografi, Lunds universitet, 22362 Lund, Sweden e-mail: mikhail.martynovich@keg.lu.se

\section{Introduction}

Entrepreneurship is predominantly a local event (Audretsch et al. 2012). Individuals tend to start businesses in the regions where they have previously lived, studied, and worked (Dahl and Sorenson 2009; Michelacci and Silva 2007). Research has explained this locational inertia of entrepreneurs by personal factors (Curran et al. 2016; Lafuente et al. 2010) and the opportunity to leverage social capital that is hardly transferable over space (Kalnins and Chung 2006; Varga and Schalk 2004).

Notwithstanding the importance of the 'local' for entrepreneurial activities, research has demonstrated that a substantial share of entrepreneurial entries is performed by individuals with a history of spatial relocation. For example, studying the technology-based cluster in Ottawa, Harrison et al. (2004) demonstrated that while most individuals started new firms nearby their immediate past employer, many of them had previously moved to the region during their careers. Investigating international in- and outmigration flows of individuals in Silicon Valley, Saxenian (2006) went as far as characterizing entrepreneurs as modern-day Argonauts roving the world in pursuit of their own golden fleeces. Taking a more systematic perspective, Frederiksen et al. (2016) demonstrated that a high rate of geographical mobility increased the probability of an individual performing an entrepreneurial entry.

Knowledge-based theories of entrepreneurship suggest that the spatial mobility of individuals - being the mechanism of geographical knowledge transferboosts the generation, diffusion, and exploitation of entrepreneurial opportunities across regional markets 
(Agarwal et al. 2007; Wright 2011). Entrepreneurs draw on the experience and networks established in different firms and places during their entire careers, and these conditions the spatial organization of activities they initiate with their businesses (Stam 2010). In that respect, the benefits of local embeddedness may be outweighed by those of acquiring knowledge and building networks across different geographical settings. However, the impact of spatial biographies of individuals-i.e. histories of switching employment regions - on their entrepreneurial activities has so far received insufficient attention in the literature (Frederiksen et al. 2016). This article is a step in this direction.

Focusing on entrepreneurial entries in the Swedish IT services sector between 1991 and 2010, the article addresses three research questions. The first question revisits the issue of locational inertia, investigating the extent of this phenomenon: In what way do spatial biographies of individuals influence their propensity to start a firm in the Swedish IT services sector?

The second question investigates whether individuals' local embeddedness or exposure to knowledge accumulation opportunities across different geographical settings matters more for the performance of their firms: In what way is the post-entry performance of new firms in the Swedish IT services sector affected by pre-entry spatial biographies of their founders?

Finally, as the investigation covers a long time period, the third question focuses on the temporal dimension of the spatial behavior of entrepreneurs: In what way was the evolution of the IT services sector over time reflected in the relationship between spatial biographies of individuals and their entrepreneurial activities?

The focus on the IT services sector is motivated by several reasons. First, being a prominent example of the new entrepreneurial economy (Audretsch and Thurik 2001), the sector has recently experienced a remarkable growth in terms of new firm formation and employment (Lasch et al. 2013). Second, it has been identified among the key nodes in knowledge networks that foster processes of knowledge creation and diffusion (Miozzo and Grimshaw 2005). Therefore, the sector is a suitable research setting for analyzing the relationship between knowledge flows associated with individual's mobility and their entrepreneurial activities. Third, IT services are often characterized as 'footloose' activities (Audretsch et al. 2011), which makes it interesting to investigate the locational behavior of entrepreneurs in the sector with (supposedly) limited spatial constraints.

The investigation is restricted to entrepreneurial entries in Swedish non-core regions for the following reasons. First, studies of entrepreneurship typically focus on metropolitan areas or, in the words of Steyaert and Katz (2004, p. 183), on 'where the light is'. Much less is, however, known about entrepreneurship in noncore regions (Bürcher et al. 2016; Baumgartner et al. 2013). Second, as the spatial distribution of IT services is city-dominated (Martynovich and Henning 2017), non-core regions offer a limited opportunity for acquiring the sector-specific knowledge that is necessary for a successful entrepreneurial entry. At the same time, such regions are characterized by a tightly woven social fabric that facilitates local networking (Atterton 2007). In that respect, non-core regions provide a suitable setting for analyzing a possible complementarity/ substitution between local embeddedness and non-local knowledge accumulated through spatial relocation.

The results of this investigation demonstrate that while entrepreneurs are, indeed, characterized by locational inertia, it is not only the location of individuals immediately prior to entrepreneurial entry but also their extended spatial biographies that matter for their entrepreneurial activities. Individuals with broad spatial relocation histories - and, thus, exposed to external knowledge acquisition opportunities - are more likely to start firms in non-core regions, and more successful ones. Non-local knowledge accumulated through spatial relocation is, therefore, claimed to be an important complement to embeddedness in local networks in non-core regions. The extent of this complementarity has, however, changed as the IT services sector and the environment around it evolved over time.

The remainder of the article is organized as follows. In Section 2, a brief review of the relevant literature is performed and the research questions are developed into hypotheses to be tested. Section 3 provides the discussion of the data, definitions, and methods employed. Section 4 presents descriptive evidence on entrepreneurship in the Swedish IT services sector. Modeling results are presented in Section 5. Section 6 positions major findings in the current debates in the literature and provides concluding remarks. 
2 Entrepreneurship in non-core regions: hypothesizing the role of individuals' spatial biographies

The spatial distribution of entrepreneurial activities is uneven (Stam 2010), which is, among other things, related to the locational behavior of individuals who start businesses. Empirical evidence suggests that entrepreneurship is, to a great extent, a local event (Audretsch et al. 2012; Sorenson and Audia 2000). That is, new firms tend to be established and stay in the regions where their founders have previously lived, studied, and worked (Pellenbarg et al. 2002; Michelacci and Silva 2007). In that respect, the question for a potential entrepreneur is often what kind of a firm to start in a given location, rather than selecting a location for a given firm (Stam 2007).

This phenomenon, known as the locational inertia of entrepreneurs (Stam and Bosma 2014), has been attributed to the willingness of individuals to remain close to family and friends (Dahl and Sorenson 2012; Gimeno et al. 1997) or attain a certain quality of life (Lafuente et al. 2010; Marcketti et al. 2006). Such personal motivations often outweigh market-related locational factors (Curran et al. 2016).

Besides, individuals are economically and relationally embedded in places (Dahl and Sorenson 2009). This embeddedness stems from location-specific social capital in the form of localized network externalities that are intangible assets with a limited transferability over space (Kalnins and Chung 2006; Varga and Schalk 2004). Spatial relocation comes at a price for individuals because it entails serious social costs as old ties are severed and new ties need to be established (Sorenson and Audia 2000). In that respect, embeddedness in local networks is a crucial factor for success of entrepreneurial entries (Butler and Hansen 1991). Entrepreneurial entries performed in the home regions of their founders tend to demonstrate higher rates of survival and profitability than those performed by relocating individuals (Dahl and Sorenson 2012).

Embeddedness in local networks improves access to information and financial resources at a pre-entry stage (Nijkamp 2003; Shane and Stuart 2002). It also plays an important role in the post-entry performance of new firms as it is conditional upon building linkages to potential partners, customers, suppliers, advisors, employees, and investors (Michelacci and Silva 2007; Zander 2004). Extended local networks facilitate this process (Westlund and Bolton 2003). In that respect, local embeddedness improves the quality of local knowledge exchange (Bürcher et al. 2016) and reduces search costs (Stam and Bosma 2014) and risks (Westlund and Bolton 2003) associated with entrepreneurial entry.

Local embeddedness is of particular importance in noncore regions as these are characterized by stronger informal networks and a more tightly woven social fabric (Atterton 2007; Dahl and Sorenson 2012). In such regions, the risktaking attitude of potential entrepreneurs is strongly embedded in the local social, economic, and cultural structures (García-Rodríguez et al. 2016; Stathopoulou et al. 2004). Besides, individual's willingness to establish a firm in a non-core region often marks a strong commitment to the local community (Stockdale 2006).

At the same time, firms benefit from tapping into a geographical variety of knowledge sources (Lorentzen 2008; Sacchetti 2009). This provides access to new knowledge (Maskell 2014) and may mitigate the risks of spatial lock-in and myopia of learning (Liu et al. 2010). Due to the increasing complexity of innovation, firms view non-local knowledge and linkages with external collaboration partners as an important way to improve their knowledge base and complement their internal activities (Doloreux et al. 2015).

Previous studies of entrepreneurs' locational behavior suggest that their locational inertia may be exaggerated. Individuals often have histories of spatial relocation in their pre-entry careers through which they accumulate the experience and knowledge necessary to start a firm (Harrison et al. 2004; Reuschke 2014). Knowledge acquisition across different geographical settings may turn these individuals into the most promising entrepreneurs (Dahl and Sorenson 2012; Frederiksen et al. 2016).

Indeed, a broad history of geographical mobility exposes individuals to a variety of geographic knowledge sources, improves their ability to communicate effectively across various knowledge domains, and reduces limitations associated with bounded rationality (Bahlmann 2015). It provides individuals with learning opportunities that are not accessible through other forms of mobility (e.g. switching jobs across firms within the same location). In that respect, the spatial mobility exposes individuals to new opportunities, which may be recognized and exploited, in different regional markets (Wright 2011). Individuals, relocating to another region, embody knowledge that may fall outside the knowledge domain of the destination region, which allows them to 
spot opportunities that are not recognized locally (Hart and Mickiewicz 2016). Besides, geographical mobility facilitates individuals' social networks building. In that respect, broad histories of spatial relocation allow reaping more efficiently benefits of geographically diverse network configurations (Bahlmann 2015).

As individuals transfer the knowledge they possess to their newly established firms (Agarwal et al. 2007; Saxenian 2006), broad histories of spatial relocation may have implications for their post-entry performance. From this perspective, the entrepreneur himself/herself may be considered a channel of external knowledge sourcing for a firm that he/she establishes, both through deploying previously accumulated knowledge and leveraging benefits of spatially diverse social networks.

Because of limited local knowledge exchange opportunities, new firms in non-core regions are particularly dependent on external knowledge sourcing (Bürcher et al. 2016; Grillitsch and Nilsson 2015). Keeble and Tyler (1995) reported a strong connection between inmigration and entrepreneurial activity in such regions. A notably important role is attached to individuals returning to their home (non-core) regions after spending some time away. Such relocation may 'bring persons with entrepreneurial $[\ldots]$ skills back into communities. [They] may be able to mobilise pre-existing networks in the community, co-opting members for new purposes' (Brown 2002, p. 16).

In summary, for individuals, relocating to a non-core region to start a business, the absence of local networks may be compensated for by deployment of non-local knowledge and external networks. In other words, a broad spatial employment history may have a positive impact on the individuals' propensity to become entrepreneurs and the performance of firms that they start. Within this group of individuals, those who return to their home regions are likely to be in the most privileged position as they can combine local embeddedness with non-local knowledge accumulated through spatial relocation.

Provided that spatial biographies of individuals matter, it may be important not only whether but also where they have relocated before starting a firm. Where workers accumulate experience and knowledge matters more than where they use it (de la Roca and Puga 2017). Prospects of knowledge acquisition depend on the combination of individuals' abilities and motivations, on the one hand, and access to jobs that offer opportunities for acquiring marketable assets, such as knowledge and social networks, on the other hand (Gordon et al. 2015). In that respect, metropolitan areas play a pronounced role.

While the development of information and communication technologies has facilitated knowledge transfer over space, evidence suggests that a relative price of knowledge has actually risen, making it important to be located in regions where knowledge is created (Audretsch and Thurik 2001). Metropolitan areas are characterized by a high density of human capital and knowledge spillovers, providing individuals with superior opportunities for learning and networking (Acs et al. 2009; Gordon 2015). Thus, such regions are attraction hotspots for individuals willing to acquire advanced knowledge and 'get on' in their careers (Glaeser and Saiz 2003). Relocation to metropolitan areas is a precondition for (if not a mechanism of) a rapid achievement of individuals' career goals (Mulder and van Ham 2005).

Having acquired relevant knowledge, some individuals move away to non-core regions, where learning opportunities are fewer, but accumulated knowledge assets can be deployed in a more efficient way (Gordon et al. 2015). The value of experience obtained through employment in a metropolitan area is maintained when individuals relocate to other places (de la Roca and Puga 2017). What is interesting, moving away from a metropolitan area often leads to an entrepreneurial entry in the destination region (Findlay et al. 2000; Reuschke 2015). Fielding (1989) referred to this as the export of a metropolitan 'entrepreneurial culture'.

In that respect, superior opportunities for learning and networking associated with employment experience in a metropolitan area are likely to put individuals in a better position for identifying and exploiting entrepreneurial opportunities when they relocate to non-core regions.

Based on the discussion above, two sets of hypotheses are formulated. The first refers to the propensity of individuals to start firms in non-core regions conditional upon their spatial biographies:

$\mathbf{H} 1_{\mathbf{a}}$ : Local individuals in non-core regions have a higher propensity for entrepreneurship than individuals relocating to non-core regions;

$\mathbf{H} 1_{\mathbf{b}}$ : Exposure to external knowledge acquisition increases the probability of individuals performing an entrepreneurial entry in a non-core region;

H1 $1_{\mathbf{c}}$ : Metropolitan employment experience increases the probability of an individual performing an entrepreneurial entry in a non-core region. 
The second set of hypotheses relates spatial biographies of individuals to the post-entry performance of their firms:

\section{$\mathbf{H} 2_{\mathbf{a}}$ : Entrepreneurial entries by local individuals in non-core regions have a better post-entry perfor- mance than entries by individuals relocating to non-core regions; \\ $\mathbf{H} 2_{\mathbf{b}}$ : Individuals' exposure to external knowledge acquisition has a positive impact on the post-entry performance of firms they start in non-core regions; $\mathbf{H} 2_{\mathbf{c}}$ : The post-entry performance of new firms in non-core regions is positively associated with met- ropolitan employment experience of their founders.}

Hypotheses $\mathbf{H} 1_{\mathbf{a}}$ and $\mathbf{H} 2_{\mathbf{a}}$ address the issue of entrepreneurs' locational inertia. Hypotheses $\mathbf{H} 1_{\mathbf{b}}$ and $\mathbf{H} 2_{\mathbf{b}}$ aim at testing whether there is a complementarity or substitution between local embeddedness and external knowledge sourcing when it comes to entrepreneurial entries in non-core regions. Finally, hypotheses $\mathbf{H} 1_{\mathbf{c}}$ and $\mathbf{H} 2_{\mathbf{c}}$ aim at testing whether employment experience in metropolitan regions plays any particular role in individuals' decision to become entrepreneurs in non-core regions and post-entry performance of their firms.

\section{Data and methodological considerations}

\subsection{Data and definitions}

The data employed in this article comes from the Longitudinal Integration Database for Health Insurance and Labor Market Studies (LISA) provided by Statistics Sweden. For each individual registered in Sweden, it contains a set of personal attributes - age, sex, education, place of residence, etc.- - as well as a linkage to the firm of his/her main employment for which types of employment, location, and industry affiliation are known.

Location of individuals and firms is recorded at the municipality level. For investigation purposes, 290 Swedish municipalities are merged into 90 local labor markets (LLMs) that are defined by statistics of commuting in the way that maximizes self-containment of commuting flows within a region (Statistics Sweden 2010). Non-core regions are defined as those beyond the metropolitan areas and their surroundings (Lagendijk and Lorentzen 2007; Malul and Bar-El 2009). In case of Sweden, the LLMs of three largest cities-Stockholm, Gothenburg, and Malmö-are considered as metropolitan regions, while the remaining 87 LLMs are classified as non-core regions.

The sampling frame is a complete set of individuals and firms in the knowledge-intensive part of the IT services sector. The latter includes five 5-digit industries under the activity code 72 'computer and related activities' in the Swedish Standard Industrial Classification, namely (1) hardware consultancy, (2) software consultancy, (3) software supply, (4) data processing, and (5) database activities. ${ }^{1}$

The article takes a 'small-business-and-firm-foundation' perspective on entrepreneurship that focuses on individual entrepreneurs and newly founded firms (Baumgartner et al. 2013). Entrepreneurial entries are defined as new legal organizations (Frederiksen et al. 2016) and were identified in two steps. First, for each year between 1991 and 2010, the sample of all firms operating in the IT services sector was derived. Second, for each year $t$, new entries were identified according to the following rule: the firm identifier existed in year $t$ but not year $t-1$. As a result, 25,457 entrepreneurial entries were identified.

Entrepreneurs are defined as founders of new firms and were identified based on the income information distinguishing between incomes derived from wages and those derived from business activities. The sample was further restricted to firms with one founder. While firms with multiple founders represent an interesting case from the knowledge-based perspective of entrepreneurship — such firms benefit from the recombination of knowledge and networks accumulated by all firm founders - including them would require composing combined measures of their founders' backgrounds, bringing unnecessary complications to the investigation. Based on this restriction, 1586 entries were excluded. The resulting dataset includes 23,871 entries, of which $7492(31.4 \%)$ were performed in non-core regions.

\footnotetext{
${ }^{1}$ Two 5-digit industries under the activity code 72 are excluded, namely (1) 'the maintenance and repair of office, accounting and computing machinery' because this industry has a different functional focus than the selected industries and is not considered as knowledgeintensive, and (2) 'other computer related activities' because this industry changed its code when the Swedish industrial classification system was revised in 2002, making it difficult to ensure a consistent observation over the whole time period.
} 


\subsection{Dependent variables and modeling issues}

The first dependent variable - propensity of an individual to become an entrepreneur - is defined as a binary variable indicating whether an individual starts a new firm in year $t$. To account for a possibility that individuals' spatial biographies may be related to any type of job switches (starting a firm vs. starting a new job), the reference group consists of individuals getting a paid job in the IT services sector in year $t$ (Nanda and Sørensen 2010). Individuals, changing their job situation at a certain time, are characterized by different opportunity structures and risk attitudes than those who do not
(Sørensen and Sharkey 2014). At the very least, the latter are more likely to be satisfied with their current job situation, implying that starting a firm at a certain point in time is not among their options. Also, as the data at hand do not allow the identification of individual's motivation behind starting a firm, it is possible at least to consider an entrepreneurial entry as a decision to change current job situation. Therefore, it is individuals who obtain a new paid job, rather than all individuals employed in the sector in year $t$, that constitute the reference group.

Formally, this variable is operationalized in the following way:

Entrepreneur $=\left\{\begin{array}{c}1, \text { if an individual starts a new firm in the IT services sector in year } t \\ 0, \text { if an individual gets a new job in the IT services sector in year } t\end{array}\right.$.

The impact of individuals' spatial biographies on their propensity for entrepreneurship is then estimated as discrete-time event history models using logistic regression (Nanda and Sørensen 2010).

The second dependent variable-post-entry performance of a new firm - is operationalized as its survival time and measured as the number of years the firm exists. Survival rates are modeled using the semi-parametric Cox proportional hazard model (Cox 1972). The advantage of this (widely used) approach is its flexibility and robustness: neither does it necessitate any assumptions about the distribution of survival rates, implying that no restrictions are imposed on the shape of the hazard function, nor does it require estimating baseline hazard.

Formally, the model is specified in the following way:

$h(t)=h_{0}(t) \times e^{X \beta}$,

where $h(t)$ is the hazard function in year $t$ after the entry, $h_{0}(t)$ the baseline hazard function (an unspecified risk of failure provided that a firm survived until year $t$ ), $X$ a vector of covariates, and $\beta$ a vector of coefficients. Parameters in the vector $\beta$ are estimated using the partial likelihood method that orders firm exits at each time point and calculates a conditional probability of failure for firms that are observed to exit. As the data is available until 2010, all firms that still exist in 2010 are right-censored but are included in the analysis prior to this year.

\subsection{Operationalizing individuals' spatial biographies}

The spatial organization of individuals' entrepreneurial activities is conditional upon their employment biographies (Stam 2010). The latter are operationalized as employment histories of individuals, i.e. changes in the employment status, regions of employment and residence, and industry of employment. These histories are constructed for a 6-year period as the annual data in LISA is available from 1985, implying that it is possible to go back a maximum of 6 years from the first considered year (1991). Three variables, capturing the spatial biographies of individuals, are specified.

The first-immediate location prior to the entry (ILE) - records whether an individual relocated within a year prior to starting a new firm and is formally defined in the following way:

$\mathrm{ILE}=\left\{\begin{array}{c}\text { Local entrant, if } \mathrm{LLM}_{t}=\mathrm{LLM}_{t-1} \\ \text { Switcher from metro, if } \mathrm{LLM}_{t} \neq \mathrm{LLM}_{t-1} \text { and } \mathrm{LLM}_{t-1} \text { is a metropolitan region } \\ \text { Switcher from non-core, if } \mathrm{LLM}_{t} \neq \mathrm{LLM}_{t-1} \text { and } \mathrm{LLM}_{t-1} \text { is a non-core region }\end{array}\right.$, 
where $\mathrm{LLM}_{t}$ is the LLM where the entry is performed in year $t$ and $\mathrm{LLM}_{t-1}$ the LLM of employment (for employed individuals) or residence (for unemployed individuals) in year $t-1$.

The second spatial biography variable - 6-year relocation pattern - captures patterns of individuals' relocation over 6 years of recorded employment history. Four relocation patterns are identified as follows:

(1) non-movers - individuals who remained employed in the same region over 6 years;

(2) one-time movers - individuals who switched employment regions once over 6 years;

(3) onward movers - individuals who switched employment regions several times over 6 years, without returning to the region of employment in the first year of recorded employment history;

(4) returners - individuals who switched employment regions several times over 6 years and returned to the region of employment in the first year of recorded employment history.

This variable provides an extended operationalization of individuals' spatial biographies. Appendix Table 6 provides hypothetical examples that demonstrate possible interaction between these two spatial biography variables.

The third spatial biography variable - metropolitan employment tenure - is the number of years within 6 years of recorded employment history that an individual was employed in a metropolitan region.

An important reservation should be made here. The data employed in this article does not allow distinguishing between the joint motivation of individuals to relocate spatially and start a business. Two situations are possible. First, a decision to relocate comes first (e.g. for personal reasons). In this case, the decision to start a firm may be driven by, for example, the absence of suitable employment opportunities in the destination region. In other words, starting a new business is the outcome of spatial relocation. Second, an individual identifies an entrepreneurial opportunity in a certain region before deciding to relocate there. In other words, the relocation decision is driven by the intention to start a firm. In that respect, the association between the spatial biography of an individual and her entrepreneurial behavior should be interpreted with caution.

\subsection{Control variables}

Entrepreneurial activities of individuals depend on their capacity to coordinate new knowledge and their knowledge acquisition efficiency (Qian and Acs 2013). Employment experience prior to starting a firm exposes individuals to different opportunity cost structures (Gimeno et al. 1997) and affects their potential to capitalize on accumulated knowledge and experience (Cohen and Levinthal 1990). These impact the ability of individuals to recognize and exploit entrepreneurial opportunities (Shane 2000). Therefore, several control variables are included in regression analyses to take account of aspects of individuals' experience that have been demonstrated to influence their entrepreneurial behavior.

First, a dummy variable (Higher education) is added to control for whether an individual possesses a university degree. Second, a dummy variable (Entrepreneurial experience) is introduced to capture whether an individual has a history of starting a firm within 6 year of recorded employment history. The literature suggests that having entrepreneurial experience positively affects the ability of an individual to identify and exploit entrepreneurial opportunities (Audretsch et al. 2006). Third, to control for the impact of prior employment, a variable measuring the number of years of employment experience in the IT services sector (Sector experience) is included. It is hypothesized to have a positive impact on both the propensity to start a new firm and its postentry performance. For instance, knowledge about technology, competitors, customer needs, etc. can often be learned only through industry participation (Klepper 2001). Besides, individuals having the employment experience in the sector can make use of social networks from their prior settings (Colombo and Grilli 2005). Finally, the length of unemployment (in years) prior to starting a firm is recorded.

Research has also highlighted the importance of demographic characteristics for individuals' entrepreneurial activity. Therefore, sex of an individual is included as a dummy variable (Sørensen 2007). Potential linear and non-linear effects of age are controlled for by introducing age and squared age of firm founders as additional variables (Dunn and Holtz-Eakin 2000).

In survival models, the controls for employment in a new firm in year of entry as well as total employment in the IT services sector in the region of the entry are included. 


\section{Entrepreneurial activity in the Swedish IT services sector}

This section presents descriptive evidence on the extent of entrepreneurship in the Swedish IT services sector between 1991 and 2010. To begin with, Fig. 1 reports the number of entrepreneurial entries performed in the sector (divided into entries in core and non-core regions) projected against the total employment in the sector.

There is a clear upward trend in both indicators. The number of entrepreneurial entries increased from 196 in 1991 to 2389 in 2010. Quite pronounced is the rapid increase in the number of new entries between 2001 and 2004. This surge in entrepreneurial activity coincided with the overall contraction of the sector in the aftermath of the 2001 dotcom crash. A possible explanation is that the adverse labor market conditions forced individuals into entrepreneurship since other employment options were not readily available (Bergmann and Sternberg 2007; Hessels et al. 2008). For individuals, laid off their jobs in the aftermath of the dotcom crash, starting a business may have been the only opportunity to remain in the sector. At the same time, given that the number of entries remained at a high level throughout the 2000s, this surge may also be explained by the evolution of the sector, in general, and the restructuring of entrepreneurial opportunities in the sector, in particular.

The distribution of entrepreneurial entries across core and non-core regions was highly unequal over the whole time period. Between 1991 and 2010, 68.5\% of new IT service firms were started in metropolitan areas. Moreover, their share increased over time: from $58.9 \%$ in 1991 to $71.4 \%$ in 2010 . This corresponds to the previously documented pattern of increased concentration of employment in the IT services sector to metropolitan areas (Martynovich and Henning 2017). Moreover, a similar trend is observed in other knowledge-intensive industries (Corrocher and Cusmano 2012; Wood 2005). It should be noted, however, that the number of entrepreneurial entries in non-core regions increased steadily over time: from 83 in 1991 to 684 in 2010.

With respect to the immediate location of individuals prior to starting a firm, a stark difference is observed between core and non-core regions (Fig. 2).

The share of entries performed by individuals who were not employed or residing in the region of entry a year before is significantly lower in core regions. While only $7.2 \%$ of new firms in metropolitan areas were started by relocating individuals between 1991 and
2010, the corresponding number in non-core regions was $22.9 \%$. A slight upward trend in the share of such entries is observed over time in both types of regions. Nevertheless, Fig. 2 supports the notion of locational inertia of entrepreneurs.

Moving to the core focus of this article, the distribution of new firms in non-core regions with respect to the immediate spatial origin of their founders is reported in Fig. 3.

Between 1991 and 2010, around 14\% of entrepreneurial entries were performed by individuals relocating from core regions. Less common were entries performed by individuals relocating between non-core regions (8.9\% of all entries). This difference increased slightly over time in favor of the former. This provides preliminary evidence on the importance of metropolitan employment experience for entrepreneurial activities in non-core regions.

In what follows, the descriptive evidence on relocation patterns of entrepreneurs in the IT services sector is complemented by an analysis of the impact of different aspects of individuals' spatial biographies on their propensity to become entrepreneurs and the post-entry performance of their firms.

\section{Regression analysis}

\subsection{Propensity for entrepreneurship}

Table 1 reports the results of estimating the propensity of individuals for entrepreneurship conditional upon their spatial biographies. Appendix Table 7 provides the sample summary as well as the correlation table for variables included in the analysis.

With respect to the immediate location prior to the entry, local entrants in non-core regions demonstrate the highest propensity to become entrepreneurs. The probability of starting a new firm as compared to starting a new job (paid employment) is $27 \%$ lower for individuals relocating from a metropolitan area within a year before entry, and $51 \%$ lower for individuals relocating from another non-core region (Model 1). In that respect, while switchers from metropolitan areas are more likely to start a new firm than switchers from other non-core regions, they are still not as entrepreneurial as local entrants.

Considering the 6-year relocation pattern of individuals starting a firm in a non-core region adds an 


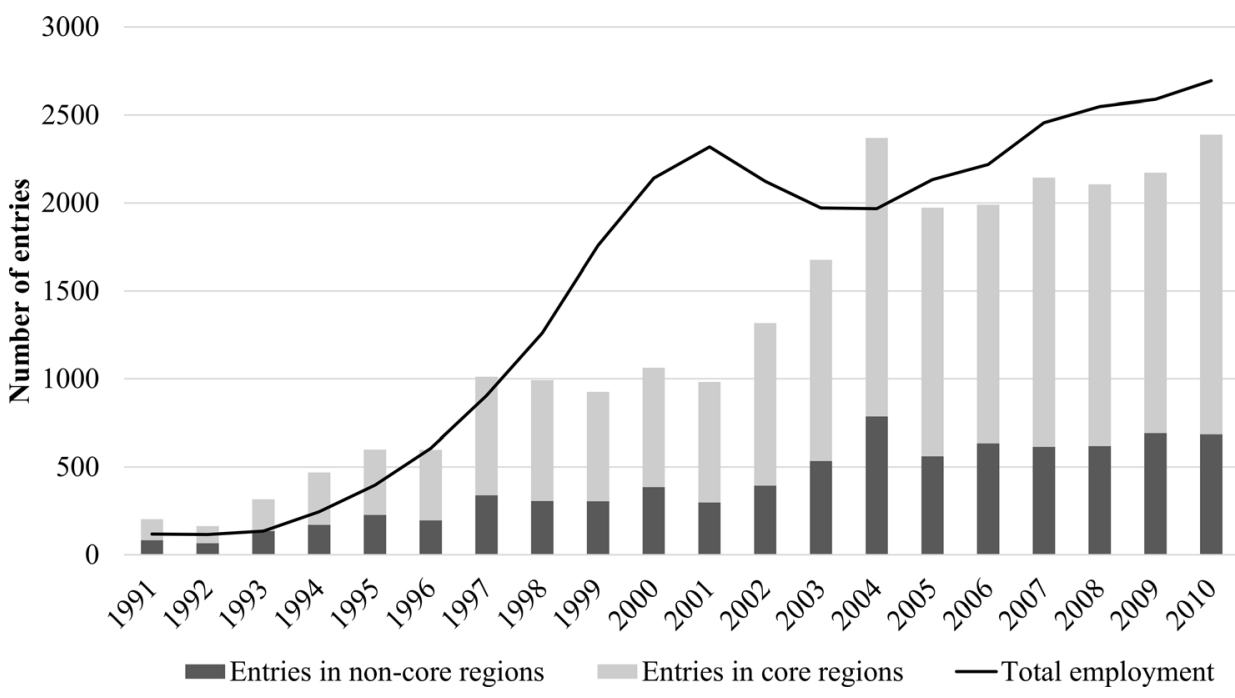

Fig. 1 Entrepreneurial entries and employment in the Swedish IT services sector

important qualification to this result. Individuals who remained employed in the same region over 6 years of recorded employment history (non-movers) demonstrate the lowest propensity for entrepreneurship (14\% less likely than one-time movers). The highest probability of becoming entrepreneurs is demonstrated by returners: they are $33 \%$ more likely to choose entrepreneurship over paid job than one-time movers. Thus, even though individuals tend to start new firms in the regions where they were employed or resided at least a year prior to the entry, estimated odds ratios for the 6year relocation pattern suggest that those with a history of spatial relocation are more likely to start a business than those without.
Moreover, the impact of the immediate location prior to the entry on the propensity for entrepreneurship covaries significantly with different histories of prior relocation over 6 years of recorded employment history (interaction term in Model 2). For instance, returners and onward movers demonstrate a higher probability of starting a new firm than one-time movers both in case of relocations from metropolitan areas and between noncore regions.

To provide a clearer perspective on the interaction between two spatial biography variables, Table 2 reports predicted probabilities of becoming entrepreneurs for individuals with different spatial biographies (controlling for other human capital variables).

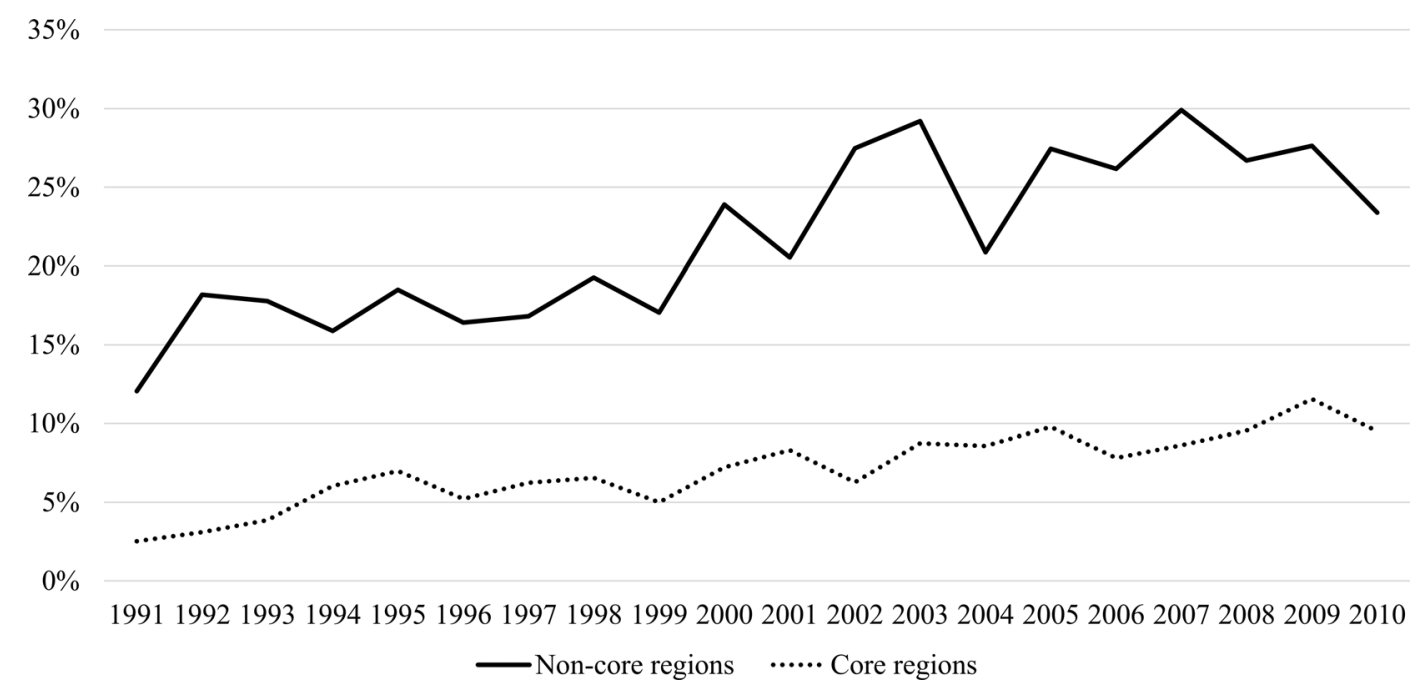

Fig. 2 Entrepreneurial entries by non-local individuals 


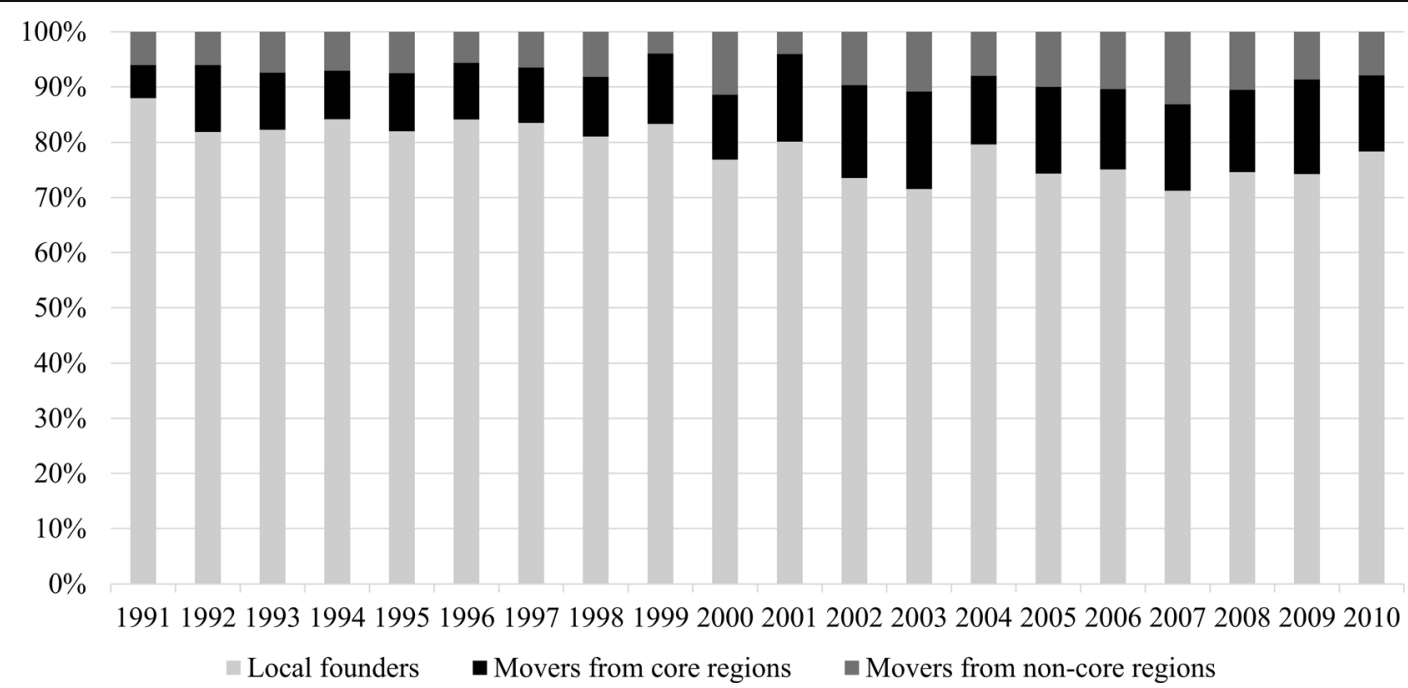

Fig. 3 Entrepreneurial entries in non-core regions

Irrespective of the 6-year relocation pattern, local entrants in non-core regions are most likely to perform an entrepreneurial entry, which supports hypothesis $\mathbf{H} 1_{\mathbf{a}}$. However, there is a heterogeneity within local entrant group with respect to the 6-year relocation pattern. Individuals with a history of spatial relocation (one-time movers, onward movers, returners) demonstrate a significantly higher probability of starting a firm than those who remained employed in the region of entry over 6 years of recorded employment history. This suggests that the input of non-local knowledge has a positive impact on the propensity of individuals for entrepreneurship, supporting hypothesis $\mathbf{H} 1_{\mathbf{b}}$.

When it comes to individuals relocating to a non-core region within a year prior to the entry, switchers from metropolitan areas are more likely to become entrepreneurs than individuals relocating between non-core regions. However, it is only returners from metropolitan regions that come at par with local entrants with respect to the propensity for entrepreneurship. In that respect, only a limited support for hypothesis $\mathbf{H} 1_{\mathbf{c}}$ is obtained.

These results suggest that it is not only the immediate location prior to the entry but also the extended spatial biography of individuals that matters for their decision to start firms in non-core regions. With regard to the importance of local embeddedness compared to exposure to external knowledge acquisition opportunities, the results imply that they operate differently for individuals performing a local entry and those who relocate within a year prior to starting a firm. For the former, having a history of spatial relocation increases the probability to become entrepreneurs, which implies that external knowledge acquisition opportunities are important for deciding to start a firm. For the latter, however, the absence of local networks is not offset by exposure to external learning (except for returners).

In summary, the results point to the complementarity between local embeddedness and non-local knowledge: the latter is important for making a decision to start a firm in a non-core regions but primarily in the case when an individual relocates to the region at least a year before starting a firm so that he/she can start building local networks. This resembles the case of the Ottawa technology cluster reported in Harrison et al. (2004). However, their conclusions are now extended to entrepreneurial entries in non-core regions.

\subsection{Post-entry survival}

Table 3 reports 3 -year survival rates ${ }^{2}$ for entries in noncore regions with respect to the 6-year relocation pattern of individuals and the number of years they spent employed in metropolitan areas over 6 years of recorded employment history.

Firms started by individuals who remain employed in the same region over 6 years of recorded employment

\footnotetext{
${ }^{2}$ Six- and nine-year survival rates were also calculated, but are not reported here. In general, the observed tendency is the same. However, the magnitude of survival rates decreases a lot when longer survival horizons are considered, which points to the fact that after some time the pre-entry spatial biography of entrepreneurs fades in importance compared to other factors.
} 
Table 1 Propensity for entrepreneurship

\begin{tabular}{|c|c|c|}
\hline Logistic regression & Model 1 & Model 2 \\
\hline \multicolumn{3}{|c|}{ Immediate location prior to the entry (local entrants) } \\
\hline Switchers from metro & $\begin{array}{l}0.7273 * * * \\
(0.0287)\end{array}$ & $\begin{array}{l}0.5761 * * * \\
(0.0366)\end{array}$ \\
\hline Switchers from non-core & $\begin{array}{l}0.4937 * * * \\
(0.0209)\end{array}$ & $\begin{array}{l}0.3209 * * * \\
(0.0246)\end{array}$ \\
\hline \multicolumn{3}{|c|}{ 6-year relocation pattern (one-time movers) } \\
\hline Non-movers & $\begin{array}{l}0.8624 * * * \\
(0.0272)\end{array}$ & $\begin{array}{l}0.7885 * * * \\
(0.0260)\end{array}$ \\
\hline Onward movers & $\begin{array}{l}1.0735 \\
(0.0423)\end{array}$ & $\begin{array}{l}0.9856 \\
(0.0540)\end{array}$ \\
\hline Returners & $\begin{array}{l}1.3268 * * * \\
(0.0500)\end{array}$ & $\begin{array}{l}0.9757 \\
(0.0497)\end{array}$ \\
\hline \multicolumn{3}{|c|}{$\begin{array}{l}\text { Immediate location prior to the entry } \times 6 \text {-year relocation pattern } \\
\text { (one-time movers) }\end{array}$} \\
\hline Onward movers from metro & & $\begin{array}{l}1.2692 * \\
(0.1230)\end{array}$ \\
\hline Onward movers from non-core & & $\begin{array}{l}1.5135 * * * \\
(0.1615)\end{array}$ \\
\hline Returners from metro & & $\begin{array}{l}1.7881 * * * \\
(0.1672)\end{array}$ \\
\hline Returners from non-core & & $\begin{array}{l}2.6428 * * * \\
(0.2807)\end{array}$ \\
\hline Higher education (no) & $\begin{array}{l}0.8830^{* * * *} \\
(0.0225)\end{array}$ & $\begin{array}{l}0.8831 * * * \\
(0.0225)\end{array}$ \\
\hline Sector experience & $\begin{array}{l}0.9114 * * * \\
(0.0061)\end{array}$ & $\begin{array}{l}0.9104 * * * \\
(0.0061)\end{array}$ \\
\hline Unemployment spell & $\begin{array}{l}1.0743 * * * \\
(0.0072)\end{array}$ & $\begin{array}{l}1.0719 * * * \\
(0.0072)\end{array}$ \\
\hline Entrepreneur experience (no) & $\begin{array}{l}4.3958 * * * \\
(0.1347)\end{array}$ & $\begin{array}{l}4.3774 * * * \\
(0.1343)\end{array}$ \\
\hline Individual controls (age, age $^{2}$, sex) & Yes & Yes \\
\hline Industry dummies & Yes & Yes \\
\hline Year dummies & Yes & Yes \\
\hline Region dummies & Yes & Yes \\
\hline Pseudo- $R^{2}$ & 0.1235 & 0.1252 \\
\hline Number & 101,789 & 101,789 \\
\hline
\end{tabular}

Odds ratios are reported. Values above 1 indicate an increased probability of becoming an entrepreneur. Robust standard errors clustered at the individual level are reported in brackets. $* * *(* *$ and $*)$ indicate a significant difference from 1 at the $0.1 \%$ (1 and 5\%) level. For categorical variables and dummies, values in the brackets are reference values

history enjoy significantly higher survival rates than firms started by other individuals without metropolitan employment experience. Here, contrary to the propensity for entrepreneurship models, the history of spatial relocation does not contribute positively to survival of new firms. This points to a higher importance of local embeddedness compared to exposure to external knowledge acquisition opportunities.

Metropolitan employment tenure tends to compensate for the absence of local embeddedness, but to a different extent for individuals with different patterns of spatial relocation over 6 years of recorded employment history. For one-time movers, it is necessary to spend at least 4 years in a metropolitan area to enjoy the same firm survival rate as non-movers. It is 3 years for onward movers. In that respect, survival rates suggest that local embeddedness and non-local knowledge obtained through employment in a metropolitan area may substitute each other.

At the same time, returners are the most privileged group among individuals with a history of spatial relocation. Not only do they need just 1 year in a metropolitan area to catch up to the firm survival rate of nonmovers but also spending long enough time being employed in a metropolitan area (5 years) makes the survival rate of their firms significantly higher than those of non-movers. In that respect, non-local knowledge obtained through employment in a metropolitan area contributes most to the post-entry performance of new firms in non-core regions when it is combined with at least some extent of local embeddedness.

Controlling for other human capital characteristics of firm founders by estimating the Cox proportional hazards model confirms the results above (Table 4). Appendix Table 8 provides the sample summary as well as the correlation table for variables included in the analysis.

The relocation pattern of individuals over 6 years of recorded employment history has a significant impact on the survival probability of a firm that they start. Entries performed by individuals staying in the same non-core region over 6 years of recorded employment history have the lowest exit probability. It is higher for individuals with a history of spatial relocation: around $12-13 \%$ higher chance of failure for one-time movers and returners and almost $30 \%$ higher-for onward movers (Model 1).

At the same time, work experience in a metropolitan area tends to compensate somewhat for disadvantages associated with the absence of local embeddedness (Metropolitan emp. tenure). Each year of firm founder's employment in metropolitan regions is associated with $2 \%$ decrease in the exit probability (though, this effect is only significant at the $10 \%$ level). 
Table 2 Predicted propensity for entrepreneurship

\begin{tabular}{|c|c|c|c|c|}
\hline \multirow[t]{2}{*}{ Immediate location prior to the entry } & \multicolumn{4}{|c|}{6 -year relocation pattern } \\
\hline & Non-movers & One-time movers & Onward movers & Returners \\
\hline Local entrants & $\begin{array}{l}0.0593 \\
(0.0012)\end{array}$ & $\begin{array}{l}0.0740 * \\
(0.0020)\end{array}$ & $\begin{array}{l}0.0735 * \\
(0.0033)\end{array}$ & $\begin{array}{l}0.0724 * \\
(0.0031)\end{array}$ \\
\hline Switchers from metro & Not identified & $\begin{array}{l}0.0442 * \\
(0.0025)\end{array}$ & $\begin{array}{l}0.0548 \\
(0.0030)\end{array}$ & $\begin{array}{l}0.0744 * \\
(0.0038)\end{array}$ \\
\hline Switchers from non-core & Not identified & $\begin{array}{l}0.0249 * \\
(0.0018)\end{array}$ & $\begin{array}{l}0.0370 * \\
(0.0021)\end{array}$ & $\begin{array}{l}0.0621 \\
(0.0036)\end{array}$ \\
\hline
\end{tabular}

Predicted probabilities are reported at the mean values of other explanatory variables. Standard errors are reported in brackets. * indicates a significant difference from the predicted propensity for entrepreneurship for non-movers at the $5 \%$ significance level

The importance of the latter is, however, conditional upon the 6-year pattern of entrepreneurs' relocation (interaction term in Model 2). Returners tend to experience the largest benefit from the metropolitan employment tenure-7\% decrease in exit probability for each year of employment in metropolitan areas. For other movers, this effect is smaller. That returners are the main beneficiaries of the metropolitan employment experience is not surprising, given that they combine the work experience in dynamic IT services clusters in metropolitan areas with the ability to leverage the social capital they have accumulated in their pre-metropolitan careers.

Modeling survival of new entrepreneurial entries provides support for hypotheses $\mathbf{H} 2_{\mathbf{a}}, \mathbf{H} 2_{\mathbf{b}}$, and $\mathbf{H} 2_{\mathbf{c}}$, though to a different extent. On the one hand, new firms established by individuals staying in the same non-core region over 6 years of recorded employment history demonstrate lower exit probabilities than firms started by individuals with a history of spatial relocation, which provides full support for hypothesis $\mathbf{H} 2_{\mathbf{a}}$. On the other hand, exposure to external knowledge acquisition opportunities through spatial relocation does not seem to improve survival rates of new entries, unless this exposure takes place in a metropolitan region. Therefore, only limited support for hypothesis $\mathbf{H} 2_{\mathbf{b}}$ is obtained. In turn, metropolitan employment experience tends to compensate for the absence of local embeddedness for one-time movers and onward movers. However, it is only returners who, due to their metropolitan employment experience, start firms with higher survival rates than those started by non-movers. In any case, there is a support for hypothesis $\mathbf{H} 2_{\mathbf{c}}$.

Table 3 Three-year survival rates

\begin{tabular}{|c|c|c|c|c|c|c|c|}
\hline \multirow[t]{2}{*}{ 6-year relocation pattern } & \multicolumn{7}{|c|}{ Metropolitan employment tenure } \\
\hline & 0 & 1 & 2 & 3 & 4 & 5 & 6 \\
\hline Non-movers & $\begin{array}{l}0.3979 \\
(0.0090)\end{array}$ & $\mathrm{n} / \mathrm{a}$ & $\mathrm{n} / \mathrm{a}$ & $\mathrm{n} / \mathrm{a}$ & $\mathrm{n} / \mathrm{a}$ & $\mathrm{n} / \mathrm{a}$ & $\mathrm{n} / \mathrm{a}$ \\
\hline One-time movers & $\begin{array}{l}0.3254 * \\
(0.0112)\end{array}$ & $\begin{array}{l}0.2729 * \\
(0.0198)\end{array}$ & $\begin{array}{l}0.3095^{*} \\
(0.0206)\end{array}$ & $\begin{array}{l}0.3379 * \\
(0.0193)\end{array}$ & $\begin{array}{l}0.3772 \\
(0.0186)\end{array}$ & $\begin{array}{l}0.4108 \\
(0.0187)\end{array}$ & $\begin{array}{l}0.4446 \\
(0.0277)\end{array}$ \\
\hline Onward movers & $\begin{array}{l}0.2610 * \\
(0.0179)\end{array}$ & $\begin{array}{l}0.3054 * \\
(0.0250)\end{array}$ & $\begin{array}{l}0.3264 * \\
(0.0316)\end{array}$ & $\begin{array}{l}0.3542 \\
(0.0372)\end{array}$ & $\begin{array}{l}0.3265 \\
(0.0379)\end{array}$ & $\begin{array}{l}0.4336 \\
(0.0542)\end{array}$ & $\begin{array}{l}0.4171 \\
(0.0819)\end{array}$ \\
\hline Returners & $\begin{array}{l}0.3151^{*} \\
(0.0169)\end{array}$ & $\begin{array}{l}0.3708 \\
(0.0276)\end{array}$ & $\begin{array}{l}0.3680 \\
(0.0312)\end{array}$ & $\begin{array}{l}0.3680 \\
(0.0312)\end{array}$ & $\begin{array}{l}0.3839 \\
(0.0296)\end{array}$ & $\begin{array}{l}0.4874 * \\
(0.0334)\end{array}$ & $\mathrm{n} / \mathrm{a}$ \\
\hline
\end{tabular}

Standard errors are reported in brackets. * indicates a significant difference from the 3 -year survival probability for non-movers at the $5 \%$ significance level

$n / a$ not applicable 
Table 4 Post-entry survival

\begin{tabular}{|c|c|c|}
\hline Cox proportional hazards model & Model 1 & Model 2 \\
\hline \multicolumn{3}{|l|}{ 6-year relocation pattern (non-movers) } \\
\hline One-time movers & $\begin{array}{l}1.1234 * * \\
(0.0436)\end{array}$ & $\begin{array}{l}1.1109 * * \\
(0.0444)\end{array}$ \\
\hline Onward movers & $\begin{array}{l}1.2996 * * * \\
(0.0597)\end{array}$ & $\begin{array}{l}1.3005 * * * \\
(0.0691)\end{array}$ \\
\hline Returners & $\begin{array}{l}1.1284 * * \\
(0.0481)\end{array}$ & $\begin{array}{l}1.1735^{* * * *} \\
(0.0560)\end{array}$ \\
\hline Metropolitan emp. tenure & $\begin{array}{l}0.9809^{\perp} \\
(0.0111)\end{array}$ & $\begin{array}{l}0.9344 * \\
(0.0274)\end{array}$ \\
\hline \multicolumn{3}{|c|}{ 6-year relocation pattern $\times$ metropolitan emp. tenure (returners) } \\
\hline One-time mover & & $\begin{array}{l}1.0617^{\perp} \\
(0.0341)\end{array}$ \\
\hline Onward mover & & $\begin{array}{l}1.0496 \\
(0.0379)\end{array}$ \\
\hline Higher education (no) & $\begin{array}{l}0.9658 \\
(0.0287)\end{array}$ & $\begin{array}{l}0.9640 \\
(0.0287)\end{array}$ \\
\hline Sector experience & $\begin{array}{l}0.9512 * * * \\
(0.0082)\end{array}$ & $\begin{array}{l}0.9515 * * * \\
(0.0082)\end{array}$ \\
\hline Unemployment spell & $\begin{array}{l}1.0185 * \\
(0.0081)\end{array}$ & $\begin{array}{l}1.0182 * \\
(0.0081)\end{array}$ \\
\hline Entrepreneur experience (no) & $\begin{array}{l}0.8967^{\perp} \\
(0.0505)\end{array}$ & $\begin{array}{l}0.8955^{*} \\
(0.0504)\end{array}$ \\
\hline Firm employment at entry & $\begin{array}{l}0.7669 \text { *** } \\
(0.0340)\end{array}$ & $\begin{array}{l}0.7671 \text { *** } \\
(0.0340)\end{array}$ \\
\hline Regional IT employment at entry (log) & $\begin{array}{l}0.9962 \\
(0.0191)\end{array}$ & $\begin{array}{l}0.9964 \\
(0.0191)\end{array}$ \\
\hline Individual controls (age, age ${ }^{2}, \mathrm{sex}$ ) & Yes & Yes \\
\hline Industry dummies & Yes & Yes \\
\hline Year dummies & Yes & Yes \\
\hline Region dummies & Yes & Yes \\
\hline$N$ of subjects & 6580 & 6580 \\
\hline$N$ of failures & 4820 & 4820 \\
\hline Log-likelihood & $-38,519.55$ & $-38,517.75$ \\
\hline
\end{tabular}

Hazard ratios are reported. Values above 1 indicate an increased probability of exit. Robust standard errors are reported in brackets. $* * *\left(* *, *\right.$, and $\left.^{\perp}\right)$ indicate a significant difference from 1 at the $0.1 \%(1,5$, and $10 \%)$ level. For categorical variables and dummies, values in the brackets are reference values

\subsection{Dynamics over time}

The surge in the number of entrepreneurial entries (Fig. 1) coupled with the increased mobility of entrepreneurs (Fig. 2) after 2000 point to a potential shift in the dynamics of entrepreneurial activities in the IT services sector. Peculiarly, this shift coincided with the 2001 dotcom crash, which played an important role in the restructuring of employment opportunities in the sector
(Warhurst et al. 2006; Martynovich and Henning 2017). This makes it interesting to check whether it was reflected also in the impact of spatial biographies of individuals on their entrepreneurial activities. Table 5 reports the results of re-estimating the models presented in Tables 1 and 4 for two sub-periods: 1991-2000 and 2001-2010. ${ }^{3}$

When it comes to the propensity for entrepreneurship (panel (a) of Table 5, see also predicted propensities in Appendix Table 9), the results, in general, confirm those for the whole time period. With respect to the immediate location prior to the entry, local individuals are more likely to become entrepreneurs in both sub-periods. However, the difference between them and individuals relocating within a year prior to the entry is reduced over time. In the first sub-period, switchers from metropoli$\tan$ areas were $45 \%$ less likely to become entrepreneurs, while switchers between non-core regions were $56 \%$ less likely. In the second sub-period, the corresponding numbers are 21 and 48\%, respectively (Models 1 and 3). At the same time, the negative impact of remaining in the same region over 6 years of recorded employment history, compared to individuals with a history of spatial relocation, becomes stronger in the second sub-period. Also, returners (particularly from metropolitan areas), which were the most likely entrepreneurs among individuals with a history of spatial relocation over the whole time period, become even more likely to choose entrepreneurship over paid job over time (Models 2 and 4). In summary, it appears that the importance of non-local knowledge compared to local embeddedness increased over time when it comes to the decision to start a firm in a non-core region.

What may lie behind this dynamic is technological advances, such as cloud computing, high-speed broadband internet, and Wi-Fi, which enabled greater entrepreneur mobility (Lafuente et al. 2010). The increased opportunities for mobility facilitated the discovery of new entrepreneurial opportunities beyond the immediate location of individuals. Besides, the diffusion of the IT as a platform for development of business activities in all kinds of regions generated an increased demand for IT services beyond metropolitan areas, implying more potential entrepreneurial opportunities in non-core regions. Individuals from metropolitan areas would be more likely to identify such opportunities as they

\footnotetext{
$\overline{{ }^{3} \text { Only variables }}$ representing spatial biographies of individuals are reported. Other estimates are available upon request.
} 
Table 5 Dynamics over time

(a) Transitions to entrepreneurship (excerpt)

\begin{tabular}{|c|c|c|c|c|}
\hline \multirow[t]{2}{*}{ Logistic regression } & \multicolumn{2}{|l|}{$1991-2000$} & \multicolumn{2}{|l|}{ 2001-2010 } \\
\hline & Model 1 & Model 2 & Model 3 & Model 4 \\
\hline \multicolumn{5}{|c|}{ Immediate location prior to the entry (local entrants) } \\
\hline Switchers from metro & $\begin{array}{l}0.5531 \text { *** } \\
(0.0445)\end{array}$ & $\begin{array}{l}0.3843 * * * \\
(0.0539)\end{array}$ & $\begin{array}{l}0.7929 * * * \\
0.0363)\end{array}$ & $\begin{array}{l}0.6509 * * * \\
(0.0471)\end{array}$ \\
\hline Switchers from non-core & $\begin{array}{l}0.4349 * * * \\
(0.0341)\end{array}$ & $\begin{array}{l}0.2145 * * * \\
(0.0332)\end{array}$ & $\begin{array}{l}0.5212 * * * \\
(0.0264)\end{array}$ & $\begin{array}{l}0.3751 * * * \\
(0.0334)\end{array}$ \\
\hline \multicolumn{5}{|c|}{ 6-year relocation pattern (one-time movers) } \\
\hline Non-movers & $\begin{array}{l}0.9433 \\
(0.0545)\end{array}$ & $\begin{array}{l}0.8357 * * \\
(0.0495)\end{array}$ & $\begin{array}{l}0.8191 * * * \\
(0.0310)\end{array}$ & $\begin{array}{l}0.7591 * * * \\
(0.0302)\end{array}$ \\
\hline Onward movers & $\begin{array}{l}1.0726 \\
(0.0811)\end{array}$ & $\begin{array}{l}0.9587 \\
(0.0960)\end{array}$ & $\begin{array}{l}1.0672 \\
(0.0496)\end{array}$ & $\begin{array}{l}0.9930 \\
(0.0655)\end{array}$ \\
\hline Returners & $\begin{array}{l}1.5989 * * * \\
(0.1099)\end{array}$ & $\begin{array}{l}1.0740 \\
(0.0969)\end{array}$ & $\begin{array}{l}1.2201 * * * \\
(0.0550)\end{array}$ & $\begin{array}{l}0.9360 \\
(0.0578)\end{array}$ \\
\hline \multicolumn{5}{|c|}{ Immediate location prior to the entry $\times 6$-year relocation pattern (one-time movers) } \\
\hline Onward movers from metro & & $\begin{array}{l}1.5067 * \\
(0.3083)\end{array}$ & & $\begin{array}{l}1.2075 \\
(0.1350)\end{array}$ \\
\hline Onward movers from non-core & & $\begin{array}{l}1.9080 * * \\
(0.4030)\end{array}$ & & $\begin{array}{l}1.3857 * * \\
(0.1730)\end{array}$ \\
\hline Returners from metro & & $\begin{array}{l}2.2091 * * * \\
(0.4238)\end{array}$ & & $\begin{array}{l}1.6714 * * * \\
(0.1815)\end{array}$ \\
\hline Returners from non-core & & $\begin{array}{l}4.4199 * * * \\
(0.8849)\end{array}$ & & $\begin{array}{l}2.1278 * * * \\
(0.2694)\end{array}$ \\
\hline Pseudo- $R^{2}$ & 0.0957 & 0.0993 & 0.1172 & 0.1184 \\
\hline Number & 45,830 & 45,830 & 55,959 & 55,959 \\
\hline
\end{tabular}

Odds ratios are reported. Values above 1 indicate an increased probability of becoming an entrepreneur. Robust standard errors clustered at the individual level are reported in brackets. $* * *(* *$ and $*)$ indicate a significant difference from 1 at the $0.1 \%(1$ and $5 \%)$ level. For categorical variables and dummies, values in the brackets are reference values.

(b) Post-entry survival (excerpt)

Cox proportional hazards model

(non-movers)

One-time movers

Onward movers

Returners

Metropolitan emp. tenure

(1)

6 -year relocation pattern $\times$ Metropolitan emp. tenure (returners)

One-time movers

Onward movers

$N$ of subjects
$1991-2000$

Model 1

1.0917

(0.0725)

1.3576 ***

(0.1112)

$1.1268^{\perp}$

(0.0778)

0.9590*

(0.0208)
Model 2

1.0747

(0.0735)

$1.3026^{* * *}$

(0.1223)

$1.2238^{* * *}$

(0.0930)

$0.8678 * *$

(0.0412)

1.1293*

(0.0617)

1.1483*

(0.0715)

1999
2001-2010

Model 3

Model 4

$1.1359 * *$
$(0.0552)$
$1.2801 * * *$
$(0.0719)$
$1.1357 * *$
$(0.0603)$
0.9891
$(0.0130)$

$1.1266^{*}$

(0.0563)

$1.3003 * * *$

(0.0842)

1.1496*

(0.0706)

0.9741

(0.0355)

1.0226

(0.0403)

1.0046

(0.0443)

4581 
Table 5 (continued)

\begin{tabular}{lllll}
\hline$N$ of failures & 1778 & 1778 & 3042 & 3042 \\
Log-likelihood & $-12,093.39$ & $-12,090.29$ & $-23,445.96$ & $-23,445.69$
\end{tabular}

Hazard ratios are reported. Values above 1 indicate an increased probability of exit. Robust standard errors are reported in brackets. ***(**, *, and $^{\perp}$ ) indicate a significant difference from 1 at the $0.1 \%(1,5$, and $10 \%)$ level. For categorical variables and dummies, values in the brackets are reference values.

were used to working in a highly competitive environment.

When it comes to survival of new firms in non-core regions, the opposite tendency is observed (panel (b) of Table 5, see also 3-year survival rates in Appendix Table 10). For instance, the benefit of remaining employed in the same region over 6 years of recorded employment history, documented for the whole time period, becomes more pronounced over time. In the 1990 s, there is no significant difference between nonmovers and one-time movers and only a weakly significant difference between non-movers and returners with respect to the exit probabilities of firms they start. These differences become significant in the 2000s. When it comes to metropolitan employment tenure, its effect is only observable in the 1990s (and quite strongly; for instance, returners enjoy a $13 \%$ decrease in failure probability for each year of employment in metropolitan regions). This effect disappears in the 2000s

This might be the other side of the story of an increased penetration of IT service firms in non-core regions. The expansion of the IT services sector beyond metropolitan areas (not least, due to an increased mobility of entrepreneurs) improved the opportunities for learning and obtaining relevant knowledge in non-core regions. Coupled with the adaptation of the educational system to the digital paradigm (Vona and Consoli 2015), this led to a decreased importance of metropolitan areas as learning regions, even if they still concentrated the majority of firms and employment opportunities. This would reduce benefits of employment experience in these regions for obtaining knowledge necessary to start a longer-surviving firm.

In summary, the modeling results for two sub-periods suggest that the relationship between spatial biographies of individuals and their entrepreneurial activities in noncore regions - and, therefore, the balance between local embeddedness and non-local knowledge-changed over time as the IT services sector matured and the environment around it changed.

\section{Discussion and conclusion}

The paper investigated the extent to which spatial biographies of individuals, that is histories of spatial relocation, have an impact on their propensity to become entrepreneurs and post-entry performance of the firms they started. The departure point was the notion of entrepreneurs' locational inertia (Audretsch et al. 2012; Dahl and Sorenson 2012), stemming from embeddedness in local networks (Dahl and Sorenson 2009). It was hypothesized that the absence of local embeddedness may be compensated for by deployment of non-local knowledge accumulated across different geographical settings (particularly, in metropolitan areas) through spatial relocation (Agarwal et al. 2007; Frederiksen et al. 2016). Empirically, the paper explored entrepreneurial entries in the IT services sector in Swedish non-core regions between 1991 and 2010.

The results demonstrate that the locational inertia of entrepreneurs, indeed, takes place. Between 1991 and 2010 , more than three quarters of entrepreneurial entries in non-core regions were performed by individuals employed or residing in the region of entry for at least 1 year prior to starting a firm. These individuals had a higher propensity to choose entrepreneurship over paid jobs. Besides, the firms they started had higher survival rates.

At the same time, the investigation suggests that there is more complexity than a simple local/non-local dichotomy of entrepreneurs' spatial origin. It was demonstrated that it is not just the location of individuals immediately prior to performing entrepreneurial entry but also their extended spatial biographies that matter for their entrepreneurial activities. It was shown that individuals with broad spatial relocation histories were more likely to become entrepreneurs, while the firms they start were, to a certain extent, characterized by higher survival rates and, thus, expected to survive longer. In that respect, it was claimed that, in case of entrepreneurial entries in non-core regions, non-local knowledge accumulated 
through spatial relocation is an important complement to embeddedness in local networks.

The analysis explored the role of work experience in metropolitan regions. The investigation suggested that the traditional role of metropolitan areas as the most fertile ground for knowledge-intensive sectors (Karlsson et al. 2010; Simmie and Strambach 2006) was complemented by their role as learning regions for individuals willing to obtain advanced knowledge in a dynamic urban context. Having work experience in metropolitan areas was demonstrated to increase the probability of an individual starting a new firm in a non-core region and of it being successful. For instance, individuals relocating from metropolitan regions within a year before entry were demonstrated to have a higher propensity for entrepreneurship than individuals relocating between non-core regions. Also, longer metropolitan employment tenure decreased the exit probability of new firms in non-core regions. This was particularly evident for individuals relocating to metropolitan areas for a while, but returning to their premetropolitan employment regions to start a business. This may have allowed them to remain embedded locally in the region of entry, but also be embedded in broader knowledge networks at the sector's level. This allows drawing parallels between such individuals and Saxenian's (2006) New Argonauts: just as the latter travelled to Silicon Valley to work in the dynamic learning context and started successful businesses upon return to their home countries, the former tended to become the most promising entrepreneurs in noncore regions.

The relationship between spatial biographies of individuals and their entrepreneurial activity was shown to have changed over time, pointing to the fact that the latter is related to the sector's evolution (Audretsch and Thurik 2003). Indeed, as an industry matures and develops, so do constraints and opportunity structures for potential entrepreneurs (Aldrich and Baker 2001). In that respect, it is important to take account of how the evolution of the sector as well as the development of the environment, in which it operates, is reflected in the entrepreneurial behavior, not least in its locational aspect.

In summary, the results of the analysis indicate that spatial biographies of individuals - and the related balance between local embeddedness and non-local knowledge - are related to the probability of entrepreneurial entry and its subsequent performance. In that respect, employment histories of individuals offer more information than simply the contents and location of the most recent employment, suggesting that those should be taken account of in future studies of the locational behavior of entrepreneurs.

\subsection{Limitations and further research}

This study comes with limitations which provide space for further investigation. First, while it was demonstrated that the sectoral context matters for the changing relationship between spatial biographies of individuals and their entrepreneurial behavior, it is quite possible that the observed dynamics may be unique to the IT services sector and/or to the stage of its development over the observed time period. Therefore, other sectors should be considered in future analyses (particularly, other knowledgeintensive industries, where mobility of entrepreneurs may be an important channel of knowledge diffusion).

Second, the analysis of post-entry performance of new firms should be extended to incorporate not only survival of new entries but also their employment and/or sales growth. This is important since previous research suggests the existence of underperforming firms which manage to survive despite low performance (Gimeno et al. 1997). Taking account of other performance indicators would allow connecting the entrepreneurial performance to development of regions, particularly in terms of upgrading their knowledge base (Neffke et al. 2014), as well as the role of entrepreneurs in the spatial diffusion of industries.

Third, the analysis points to the fact that non-local knowledge (compared to local embeddedness) plays a more important role in the propensity of individuals for entrepreneurship than for survival of entrepreneurial entries in non-core regions, which might be attributed to a different impact of non-local knowledge on the recognition vs. exploitation of entrepreneurial opportunities. That remains speculation at this point, but deserves further detailed investigation.

Finally, the data employed in this paper did not allow much to be said about individuals' motivations, either with regards to the decision to start a firm, or the decision to relocate. In that respect, deeper qualitative studies of the relationship between spatial biographies of individuals and their entrepreneurial behavior might offer a more detailed perspective on the issue. 
Acknowledgements The author would like to thank three anonymous reviewers for their constructive comments and suggestions. The author is grateful for the constructive advice and critical comments on earlier versions of this paper by Martin Henning, Karl-Johan Lundquist, Rikard Eriksson, Christian Østergaard, Ron Boschma, David Rigby, Emelie Hane-Weijman, and Agnes Andersson Djurfeldt. The paper benefited from the fruitful discussions at the Workshop on Industry Relatedness and Regional Change held in Umeå, Sweden, on October 29-31, 2014; the DRUID Academy Conference 2015 held in Aalborg, Denmark, on January 18-20, 2015; and the Annual Meeting of the American Association of Geographers held in Chicago, IL, USA, on April 21-25, 2015.

\section{Appendix}

Table 6 Spatial biographies of individuals. Hypothetical examples. There are ten possible interactions between the variables Immediate location prior to the entry and 6-year relocation pattern. They are presented in the table below along with hypothetical spatial biographies of individuals that correspond to each of possible combinations. For demonstration purposes, it is assumed that individuals A-J perform an entrepreneurial entry in year $t$ in the local labor market of Växjö (non-core region). Also, hypothetical spatial biographies include employment periods in Stockholm (core/metropolitan region) and Linköping (non-core region)

\begin{tabular}{|c|c|c|c|c|c|c|c|c|c|}
\hline Individual & $t-6$ & $t-5$ & $t-4$ & $t-3$ & $t-2$ & $t^{-1}$ & $\begin{array}{l}t \\
\text { (entry) }\end{array}$ & $\begin{array}{l}\text { Immediate location } \\
\text { prior to the entry }\end{array}$ & $\begin{array}{l}6 \text {-year } \\
\text { relocation } \\
\text { pattern }\end{array}$ \\
\hline A & Växjö & Växjö & Växjö & Växjö & Växjö & Växjö & Växjö & Local entrant & Non-mover \\
\hline B & Linköping & Linköping & Linköping & Linköping & Växjö & Växjö & Växjö & Local entrant & $\begin{array}{l}\text { One-time } \\
\text { mover }\end{array}$ \\
\hline $\mathrm{C}$ & Stockholm & Stockholm & Linköping & Linköping & Växjö & Växjö & Växjö & Local entrant & Onward mover \\
\hline $\mathrm{D}$ & Växjö & Växjö & Växjö & Linköping & Linköping & Växjö & Växjö & Local entrant & Returner \\
\hline $\mathrm{E}$ & Stockholm & Stockholm & Stockholm & Stockholm & Stockholm & Stockholm & Växjö & Switcher from metro & $\begin{array}{c}\text { One-time } \\
\text { mover }\end{array}$ \\
\hline $\mathrm{F}$ & Linköping & Linköping & Stockholm & Stockholm & Stockholm & Stockholm & Växjö & Switcher from metro & Onward mover \\
\hline $\mathrm{G}$ & Växjö & Växjö & Växjö & Stockholm & Stockholm & Stockholm & Växjö & Switcher from metro & Returner \\
\hline $\mathrm{H}$ & Linköping & Linköping & Linköping & Linköping & Linköping & Linköping & Växjö & Switcher from non-core & $\begin{array}{l}\text { One-time } \\
\text { mover }\end{array}$ \\
\hline I & Stockholm & Stockholm & Linköping & Linköping & Linköping & Linköping & Växjö & Switcher from non-core & Onward mover \\
\hline $\mathrm{J}$ & Växjö & Växjö & Växjö & Linköping & Linköping & Linköping & Växjö & Switcher from non-core & Returner \\
\hline
\end{tabular}

Note that the category 'non-mover' in the 6-year relocation pattern variable can only co-occur with the category 'local entrant' in the Immediate location prior to the entry variable 


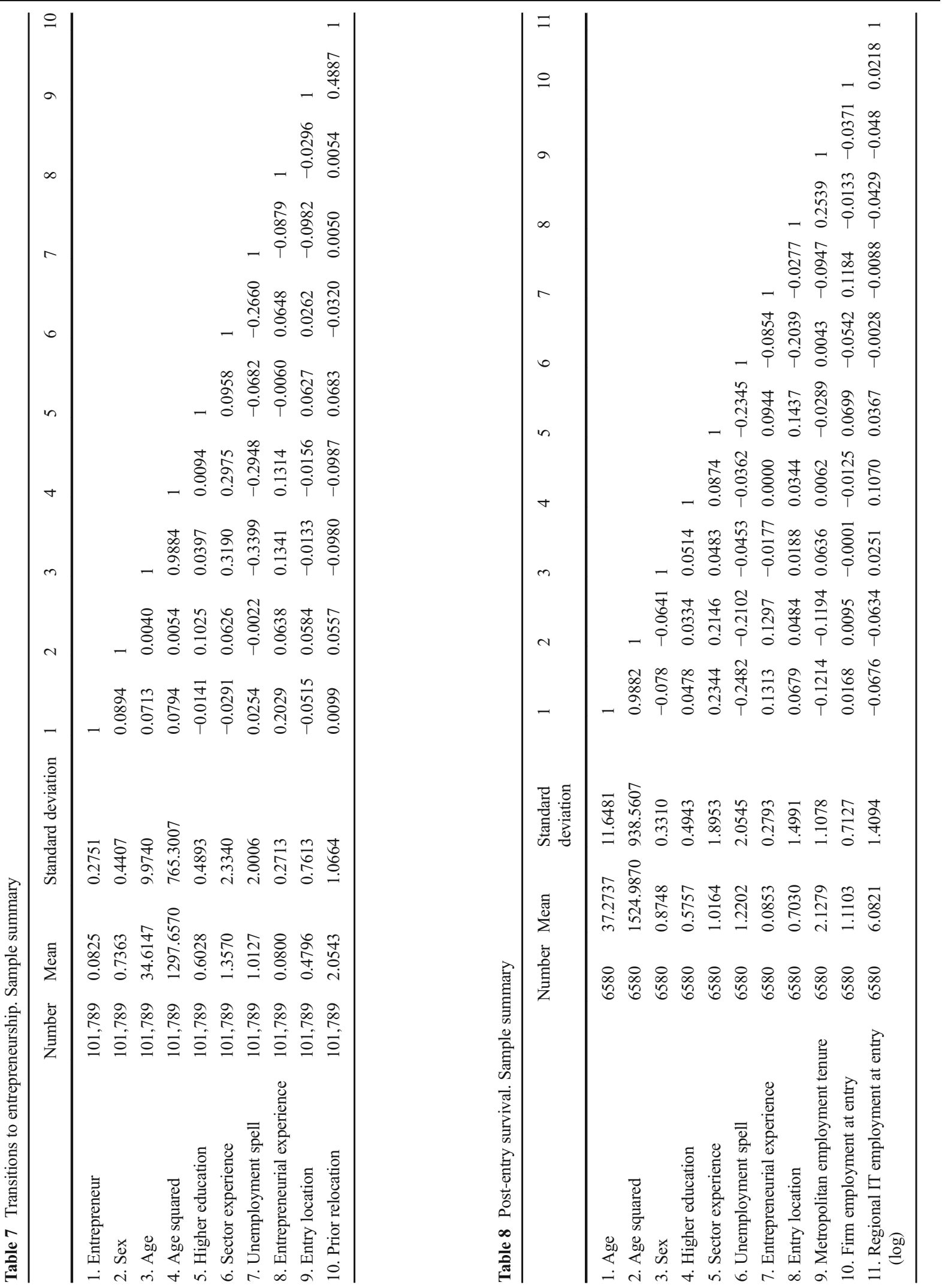


Table 9 Predicted propensity for entrepreneurship

\begin{tabular}{|c|c|c|c|c|}
\hline \multirow[t]{2}{*}{ Immediate location prior to the entry } & \multicolumn{4}{|c|}{ 6-year relocation pattern } \\
\hline & Non-movers & One-time movers & Onward movers & Returners \\
\hline \multicolumn{5}{|l|}{ (a) 1991-2000 } \\
\hline Local entrants & $\begin{array}{l}0.0406 \\
(0.0015)\end{array}$ & $\begin{array}{l}0.0481 * \\
(0.0023)\end{array}$ & $\begin{array}{l}0.0462 \\
(0.0041)\end{array}$ & $\begin{array}{l}0.0514 * \\
(0.0039)\end{array}$ \\
\hline Switchers from metro & Not identified & $\begin{array}{l}0.0190 * \\
(0.0025)\end{array}$ & $\begin{array}{l}0.0274 * \\
(0.0034)\end{array}$ & $\begin{array}{l}0.0440 \\
(0.0047)\end{array}$ \\
\hline Switchers from non-core & Not identified & $\begin{array}{l}0.0107 * \\
(0.0016)\end{array}$ & $\begin{array}{l}0.0194 * \\
(0.0022)\end{array}$ & $\begin{array}{l}0.0490 \\
(0.0047)\end{array}$ \\
\hline \multicolumn{5}{|l|}{ (b) 2001-2010 } \\
\hline Local entrants & $\begin{array}{l}0.0792 \\
(0.0018)\end{array}$ & $\begin{array}{l}0.1021 * \\
(0.0031)\end{array}$ & $\begin{array}{l}0.1028 * \\
(0.0054)\end{array}$ & $\begin{array}{l}0.0964 * \\
(0.0048)\end{array}$ \\
\hline Switchers from metro & Not identified & $\begin{array}{l}0.0694 \\
(0.0043)\end{array}$ & $\begin{array}{l}0.0824 \\
(0.0050)\end{array}$ & $\begin{array}{l}0.1039 * \\
(0.0060)\end{array}$ \\
\hline Switchers from non-core & Not identified & $\begin{array}{l}0.0409 * \\
(0.0034)\end{array}$ & $\begin{array}{l}0.0561 * \\
(0.0036)\end{array}$ & $\begin{array}{l}0.0785 \\
(0.0054)\end{array}$ \\
\hline
\end{tabular}

Predicted probabilities are reported at the mean values of other explanatory variables. Standard errors are reported in brackets. $*$ indicates a significant difference from the predicted propensity for entrepreneurship for non-movers at the $5 \%$ significance level

Table 10 Three-year survival rates

\begin{tabular}{|c|c|c|c|c|c|c|c|}
\hline \multirow[t]{2}{*}{ 6-year relocation pattern } & \multicolumn{7}{|c|}{ Metropolitan employment tenure } \\
\hline & 0 & 1 & 2 & 3 & 4 & 5 & 6 \\
\hline \multicolumn{8}{|l|}{ (a) 1991-2000 } \\
\hline Non-movers & $\begin{array}{l}0.4099 \\
(0.0154)\end{array}$ & $\mathrm{n} / \mathrm{a}$ & $\mathrm{n} / \mathrm{a}$ & $\mathrm{n} / \mathrm{a}$ & $\mathrm{n} / \mathrm{a}$ & $\mathrm{n} / \mathrm{a}$ & $\mathrm{n} / \mathrm{a}$ \\
\hline One-time movers & $\begin{array}{l}0.3216 * \\
(0.0191)\end{array}$ & $\begin{array}{l}0.2679 * \\
(0.0342)\end{array}$ & $\begin{array}{l}0.3171 * \\
(0.0363)\end{array}$ & $\begin{array}{l}0.3152 * \\
(0.0343)\end{array}$ & $\begin{array}{l}0.3726 \\
(0.0332)\end{array}$ & $\begin{array}{l}0.3929 \\
(0.0377)\end{array}$ & $\begin{array}{l}0.4932 \\
(0.0585)\end{array}$ \\
\hline Onward movers & $\begin{array}{l}0.2402 * \\
(0.0299)\end{array}$ & $\begin{array}{l}0.2935^{*} \\
(0.0475)\end{array}$ & $\begin{array}{l}0.2167 * \\
(0.0532)\end{array}$ & $\begin{array}{l}0.3043 \\
(0.0678)\end{array}$ & $\begin{array}{l}0.3514 \\
(0.0785)\end{array}$ & $\begin{array}{l}0.5625 \\
(0.1240)\end{array}$ & $\begin{array}{l}0.4444 \\
(0.1656)\end{array}$ \\
\hline Returners & $\begin{array}{l}0.3282^{*} \\
(0.0290)\end{array}$ & $\begin{array}{l}0.2963 * \\
(0.0393)\end{array}$ & $\begin{array}{l}0.3854 \\
(0.0497)\end{array}$ & $\begin{array}{l}0.4262 \\
(0.0633)\end{array}$ & $\begin{array}{l}0.5100 * \\
(0.0508)\end{array}$ & $\begin{array}{l}0.5231^{*} \\
(0.0581)\end{array}$ & $\mathrm{n} / \mathrm{a}$ \\
\hline \multicolumn{8}{|l|}{ (b) 2001-2010 } \\
\hline Non-movers & $\begin{array}{l}0.3920 \\
(0.0154)\end{array}$ & $\mathrm{n} / \mathrm{a}$ & $\mathrm{n} / \mathrm{a}$ & $\mathrm{n} / \mathrm{a}$ & $\mathrm{n} / \mathrm{a}$ & $\mathrm{n} / \mathrm{a}$ & $\mathrm{n} / \mathrm{a}$ \\
\hline One-time movers & $\begin{array}{l}0.3262 * \\
(0.0138)\end{array}$ & $\begin{array}{l}0.2743 * \\
(0.0244)\end{array}$ & $\begin{array}{l}0.3064 * \\
(0.0252)\end{array}$ & $\begin{array}{l}0.3492 * \\
(0.0283)\end{array}$ & $\begin{array}{l}0.3804 \\
(0.0225)\end{array}$ & $\begin{array}{l}0.4159 \\
(0.0215)\end{array}$ & $\begin{array}{l}0.4304 \\
(0.0315)\end{array}$ \\
\hline Onward movers & $\begin{array}{l}0.2719 * \\
(0.0223)\end{array}$ & $\begin{array}{l}0.3094 * \\
(0.0295)\end{array}$ & $\begin{array}{l}0.3680 \\
(0.0378)\end{array}$ & $\begin{array}{l}0.3739 \\
(0.0443)\end{array}$ & $\begin{array}{l}0.3206 \\
(0.0434)\end{array}$ & $\begin{array}{l}0.4016 \\
(0.0602)\end{array}$ & $\begin{array}{l}0.4082 \\
(0.0949)\end{array}$ \\
\hline Returners & $\begin{array}{l}0.3074^{*} \\
(0.0208)\end{array}$ & $\begin{array}{l}0.3213^{*} \\
(0.0285)\end{array}$ & $\begin{array}{l}0.3659 \\
(0.0333)\end{array}$ & $\begin{array}{l}0.3489 \\
(0.0358)\end{array}$ & $\begin{array}{l}0.3792 \\
(0.0339)\end{array}$ & $\begin{array}{l}0.4733 \\
(0.0459)\end{array}$ & $\mathrm{n} / \mathrm{a}$ \\
\hline
\end{tabular}

Standard errors are reported in brackets. * indicates a significant difference from the 3 -year survival probability for non-movers at the $5 \%$ significance level

$n / a$ not applicable 
Open Access This article is distributed under the terms of the Creative Commons Attribution 4.0 International License (http:// creativecommons.org/licenses/by/4.0/), which permits unrestricted use, distribution, and reproduction in any medium, provided you give appropriate credit to the original author(s) and the source, provide a link to the Creative Commons license, and indicate if changes were made.

\section{References}

Acs, Z. J., Braunerhjelm, P., Audretsch, D. B., \& Carlsson, B. (2009). The knowledge spillover theory of entrepreneurship. Small Business Economics, 32(1), 15-30. doi:10.1007 /s11187-008-9157-3.

Agarwal, R., Audretsch, D., \& Sarkar, M. B. (2007). The process of creative construction: knowledge spillovers, entrepreneurship, and economic growth. Strategic Entrepreneurship Journal, 1(3-4), 263-286. doi:10.1002/sej.36.

Aldrich, H. E., \& Baker, T. (2001). Learning and legitimacy: entrepreneurial responses to constraints on the emergence of new populations and organizations. In C. B. Schoonhoven \& E. Romanelli (Eds.), The entrepreneurship dynamic: origins of entrepreneurship and the evolution of industries (pp. 207-235). Stanford, CA: Stanford University Press.

Atterton, J. (2007). The 'strength of weak ties': social networking by business owners in the highlands and islands of Scotland. Sociologia Ruralis, 47(3), 228-245. doi:10.1111/j.14679523.2007.00435.x.

Audretsch, D. B., Falck, O., Feldman, M. P., \& Heblich, S. (2012). Local entrepreneurship in context. Regional Studies, 46(3), 379-389. doi:10.1080/00343404.2010.490209.

Audretsch, D. B., Grilo, I., \& Thurik, A. R. (2011). Globalization, entrepreneurship and the region. In M. Fritsch (Ed.), Handbook of research on entrepreneurship and regional development (pp. 11-32). Cheltenham and Northampton, MA: Edward Elgar.

Audretsch, D. B., Keilbach, M. C., \& Lehmann, E. E. (2006). Entrepreneurship and economic growth. New York: Oxford University Press.

Audretsch, D. B., \& Thurik, R. A. (2001). What's new about the new economy? Sources of growth in the managed and entrepreneurial economies. Industrial and Corporate Change, 10(1), 267-315. doi:10.1093/icc/10.1.267.

Audretsch, D. B., \& Thurik, R. A. (2003). Entrepreneurship, industry evolution and economic growth. In R. Koppl, J. Birner, \& P. Kurrild-Klitgaard (Eds.), Austrian economics and entrepreneurial studies (Advances in Austrian economics, volume 6) (pp. 39-56). Bingley: Emerald Group Publishing Limited.

Bahlmann, M. D. (2015). Finding value in geographic diversity through prior experience and knowledge integration: a study of ventures' innovative performance. Industrial and Corporate Change. doi:10.1093/icc/dtv041.

Baumgartner, D., Pütz, M., \& Seidl, I. (2013). What kind of entrepreneurship drives regional development in European noncore regions? A literature review on empirical entrepreneurship research. European Planning Studies, 21(8), 1095-1127. doi:10.1080/09654313.2012.722937.

Bergmann, H., \& Sternberg, R. (2007). The changing face of entrepreneurship in Germany. Small Business Economics, 28(2), 205-221. doi:10.1007/s11187-006-9016-z.

Brown, D. L. (2002). Migration and community: social networks in a multilevel world*. Rural Sociology, 67(1), 1-23. doi:10.1111/j.1549-0831.2002.tb00091.x.

Butler, J. E., \& Hansen, G. S. (1991). Network evolution, entrepreneurial success, and regional development. Entrepreneurship \& Regional Development, 3(1), 1-16. doi:10.1080/08985629100000001.

Bürcher, S., Habersetzer, A., \& Mayer, H. (2016). Entrepreneurship in peripheral regions: a relational perspective. In E. Mack \& H. Qian (Eds.), Geographies of entrepreneurship (pp. 143-164). London and New York: Routledge.

Cohen, W. M., \& Levinthal, D. A. (1990). Absorptive capacity: a new perspective on learning and innovation. Administrative Science Quarterly, 35(1), 128-152. doi:10.2307/2393553.

Colombo, M. G., \& Grilli, L. (2005). Founders' human capital and the growth of new technology-based firms: a competencebased view. Research Policy, 34(6), 795-816. doi:10.1016/j. respol.2005.03.010.

Corrocher, N., \& Cusmano, L. (2012). The 'KIBS engine' of regional innovation systems: empirical evidence from European regions. Regional Studies, 48(7), 1212-1226. doi:10.1080/00343404.2012.731045.

Cox, D. R. (1972). Regression models and life-tables. Journal of the Royal Statistical Society Series B (Methodological), 34(2), 187-220.

Curran, D., Lynn, T., \& O'Gorman, C. (2016). The role of personal factors in the location decision of software services start-up firms. European Planning Studies, 24(3), 551-567. doi:10.1080/09654313.2015.1046369.

Dahl, M., \& Sorenson, O. (2009). The embedded entrepreneur. European Management Review, 6(3), 172-181. doi:10.1057 /emr.2009.14.

Dahl, M., \& Sorenson, O. (2012). Home sweet home: entrepreneurs' location choices and the performance of their ventures. Management Science, 58(6), 1059-1071. doi:10.1287 /mnsc. 1110.1476.

de la Roca, J., \& Puga, D. (2017). Learning by working in big cities. The Review of Economic Studies, 84(1), 106-142. doi:10.1093/restud/rdw031.

Doloreux, D., Shearmur, R., \& Guillaume, R. (2015). Collaboration, transferable and non-transferable knowledge, and innovation: a study of a cool climate wine industry (Canada). Growth and Change, 46(1), 16-37. doi:10.1111 /grow. 12090.

Dunn, T., \& Holtz-Eakin, D. (2000). Financial capital, human capital, and the transition to self-employment: evidence from intergenerational links. Journal of Labor Economics, 18(2), 282-305. doi:10.1086/209959.

Fielding, A. J. (1989). Inter-regional migration and social change: a study of South East England based upon data from the longitudinal study. Transactions of the Institute of British Geographers, 14(1), 24-36. doi:10.2307/622340.

Findlay, A. M., Short, D., \& Stockdale, A. (2000). The labour-market impact of migration to rural areas. Applied Geography, 20(4), 333-348. doi:10.1016 /S0143-6228(00)00012-6. 
Frederiksen, L., Wennberg, K., \& Balachandran, C. (2016). Mobility and entrepreneurship: evaluating the scope of knowledge-based theories of entrepreneurship. Entrepreneurship Theory and Practice, 40(2), 359-380. doi:10.1111/etap.12223.

García-Rodríguez, F. J., Gil-Soto, E., Ruiz-Rosa, I., \& Gutiérrez-Taño, D. (2016). Entrepreneurial process in peripheral regions: the role of motivation and culture. European Planning Studies, 1-20. doi:10.1080 /09654313.2016.1262827.

Gimeno, J., Folta, T. B., Cooper, A. C., \& Woo, C. Y. (1997). Survival of the fittest? Entrepreneurial human capital and the persistence of underperforming firms. Administrative Science Quarterly, 42(4), 750-783. doi:10.2307/2393656.

Glaeser, E. L., \& Saiz, A. (2003). The rise of the skilled City. National Bureau of Economic Research Working Paper Series No. 10191

Gordon, I. R. (2015). Ambition, human capital acquisition and the metropolitan escalator. Regional Studies, 49(6), 1042-1055. doi:10.1080/00343404.2013.799767.

Gordon, I. R., Champion, T., \& Coombes, M. (2015). Urban escalators and interregional elevators: the difference that location, mobility, and sectoral specialisation make to occupational progression. Environment and Planning A, 47(3), 588-606. doi:10.1068/a130125p.

Grillitsch, M., \& Nilsson, M. (2015). Innovation in peripheral regions: do collaborations compensate for a lack of local knowledge spillovers? The Annals of Regional Science, 54(1), 299-321. doi:10.1007/s00168-014-0655-8.

Harrison, R. T., Cooper, S. Y., \& Mason, C. M. (2004). Entrepreneurial activity and the dynamics of technologybased cluster development: the case of Ottawa. Urban Studies, 41(5-6), 1045-1070. doi:10.1080 /00420980410001675841.

Hart, M., \& Mickiewicz, T. (2016). Ambitious entrepreneurship and migration: a multi-level study across the local authorities in England and Wales. ERC Research Paper No. 47. Coventry and Birmingham: Enterprise research Centre

Hessels, J., Gelderen, M., \& Thurik, R. (2008). Entrepreneurial aspirations, motivations, and their drivers. Small Business Economics, 31(3), 323-339. doi:10.1007/s11187-008-9134-x.

Kalnins, A., \& Chung, W. (2006). Social capital, geography, and survival: Gujarati immigrant entrepreneurs in the U.S. lodging industry. Management Science, 52(2), 233-247. doi:10.1287/mnsc.1050.0481.

Karlsson, C., Maier, G., Trippl, M., Siedschlag, I., Owen, R., \& Murphy, G. (2010). IT and regional economic dynamics: a literature review. EUR 24510 EN. Luxembourg: Publications Office of the European Union.

Keeble, D., \& Tyler, P. (1995). Enterprising behaviour and the urban-rural shift. Urban Studies, 32(6), 975-997. doi:10.1080/00420989550012753.

Klepper, S. (2001). Employee startups in high-tech industries. Industrial and Corporate Change, 10(3), 639-674. doi:10.1093/icc/10.3.639.

Lafuente, E., Vaillant, Y., \& Serarols, C. (2010). Location decisions of knowledge-based entrepreneurs: why some Catalan KISAs choose to be rural? Technovation, 30(11-12), 590600. doi:10.1016/j.technovation.2010.07.004.

Lagendijk, A., \& Lorentzen, A. (2007). Proximity, knowledge and innovation in peripheral regions. On the intersection between geographical and organizational proximity. European Planning Studies, 15(4), 457-466. doi:10.1080 /09654310601133260.

Lasch, F., Robert, F., \& Le Roy, F. (2013). Regional determinants of ICT new firm formation. Small Business Economics, 40(3), 671-686. doi:10.1007/s11187-011-9382-z.

Liu, X., Wright, M., Filatotchev, I., Dai, O., \& Lu, J. (2010). Human mobility and international knowledge spillovers: evidence from high-tech small and medium enterprises in an emerging market. Strategic Entrepreneurship Journal, 4(4), 340-355. doi:10.1002/sej.100.

Lorentzen, A. (2008). Knowledge networks in local and global space. Entrepreneurship \& Regional Development, 20(6), 533-545. doi:10.1080/08985620802462124.

Malul, M., \& Bar-El, R. (2009). The gap between free market and social optimum in the location decision of economic activity. Urban Studies, 46(10), 2045-2059. doi:10.1177 /0042098009339427.

Marcketti, S. B., Niehm, L. S., \& Fuloria, R. (2006). An exploratory study of lifestyle entrepreneurship and its relationship to life quality. Family and Consumer Sciences Research Journal, 34(3), 241-259. doi:10.1177/1077727X05283632.

Martynovich, M., \& Henning, M. (2017). Labour force building in a rapidly expanding sector. Industry and Innovation, 1-29. doi:10.1080/13662716.2017.1291330.

Maskell, P. (2014). Accessing remote knowledge - the roles of trade fairs, pipelines, crowdsourcing and listening posts. Journal of Economic Geography, 14(5), 883-902. doi:10.1093/jeg/lbu002.

Michelacci, C., \& Silva, O. (2007). Why so many local entrepreneurs? Review of Economics and Statistics, 89(4), 615-633. doi:10.1162/rest.89.4.615.

Miozzo, M., \& Grimshaw, D. (2005). Does EDS add value? The expansion of IT outsourcing and the nature and role of computer services firms. Paper presented at the DRUID Tenth Anniversary Summer Conference 2005, Copenhagen, Denmark, June 27-29, 2005.

Mulder, C. H., \& van Ham, M. (2005). Migration histories and occupational achievement. Population, Space and Place, 11(3), 173-186. doi:10.1002/psp.365.

Nanda, R., \& Sørensen, J. B. (2010). Workplace peers and entrepreneurship. Management Science, 56(7), 1116-1126.

Neffke, F., Hartog, M., Boschma, R., \& Henning, M. (2014). Agents of structural change. The role of firms and entrepreneurs in regional diversification. Papers in Evolutionary Economic Geography (PEEG) 1410. Utrecht, the Netherlands: Utrecht University.

Nijkamp, P. (2003). Entrepreneurship in a modern network economy. Regional Studies, 37(4), 395-405. doi:10.1080 /0034340032000074424.

Pellenbarg, P. H., van Wissen, L. J. G., \& van Dijk, J. (2002). Firm migration. In P. McCann (Ed.), Industrial location economics (pp. 110-150). Cheltenham and Northampton, MA: Edward Elgar.

Qian, H., \& Acs, Z. J. (2013). An absorptive capacity theory of knowledge spillover entrepreneurship. Small Business Economics, 40(2), 185-197. doi:10.1007/s11187-011-9368-x.

Reuschke, D. (2014). Self-employment, internal migration and place embeddedness. Population, Space and Place, 20(3), 235-249. doi:10.1002/psp.1759. 
Reuschke, D. (2015). Self-employment as a route in and out of Britain's South East. Regional Studies, 49(4), 665-680. doi:10.1080/00343404.2013.799764.

Sacchetti, S. (2009). Why, where and with whom do you link? The nature and motivations of linkages within and outside an Italian local system. Regional Studies, 43(2), 197-209. doi:10.1080/00343400701808840.

Saxenian, A. (2006). The new Argonauts: regional advantage in a global economy. Cambridge, MA: Harvard University Press.

Shane, S. (2000). Prior knowledge and the discovery of entrepreneurial opportunities. Organization Science, 11(4), 448-469. doi:10.1287/orsc.11.4.448.14602.

Shane, S., \& Stuart, T. (2002). Organizational endowments and the performance of university start-ups. Management Science, 48(1), 154-170. doi:10.1287/mnsc.48.1.154.14280.

Simmie, J., \& Strambach, S. (2006). The contribution of KIBS to innovation in cities: an evolutionary and institutional perspective. Journal of Knowledge Management, 10(5), 26-40. doi:10.1108/13673270610691152.

Sorenson, O., \& Audia, P. G. (2000). The social structure of entrepreneurial activity: geographic concentration of footwear production in the United States, 1940-1989. American Journal of Sociology, 106(2), 424-462. doi:10.1086/316962.

Stam, E. (2007). Why butterflies don't leave: locational behavior of entrepreneurial firms. Economic Geography, 83(1), 27-50.

Stam, E. (2010). Entrepreneurship, evolution and geography. In R. Boschma \& R. Martin (Eds.), The handbook of evolutionary economic geography (pp. 139-161). Cheltenham and Northampton, MA: Edward Elgar.

Stam, E., \& Bosma, N. (2014). Growing entrepreneurial economies. In T. Baker \& F. Welter (Eds.), The Routledge companion to entrepreneurship (pp. 325-340). London: Routledge.

Stathopoulou, S., Psaltopoulos, D., \& Skuras, D. (2004). Rural entrepreneurship in Europe: a research framework and agenda. International Journal of Entrepreneurial Behavior \& Research, 10(6), 404 425. doi:10.1108/13552550410564725.

Statistics Sweden. (2010). Lokala arbetsmarknader-egenskaper, utveckling och funktion. Örebro, Sweden: SCB.
Steyaert, C., \& Katz, J. (2004). Reclaiming the space of entrepreneurship in society: geographical, discursive and social dimensions. Entrepreneurship and Regional Development, 16(3), 179-196. doi:10.1080/0898562042000197135.

Stockdale, A. (2006). Migration: pre-requisite for rural economic regeneration? Journal of Rural Studies, 22(3), 354-366. doi:10.1016/j.jrurstud.2005.11.001.

Sørensen, J. B. (2007). Bureaucracy and entrepreneurship: workplace effects on entrepreneurial entry. Administrative Science Quarterly, 52(3), 387-412. doi:10.2189/asqu.52.3.387.

Sørensen, J. B., \& Sharkey, A. J. (2014). Entrepreneurship as a mobility process. American Sociological Review, 79(2), 328-349. doi: $10.1177 / 0003122414521810$.

Varga, A., \& Schalk, H. (2004). Knowledge spillovers, agglomeration and macroeconomic growth: an empirical approach. Regional Studies, 38(8), 977-989. doi:10.1080 /0034340042000280974.

Warhurst, C., Lockyer, C., \& Dutton, E. (2006). IT jobs: opportunities for all? New Technology, Work and Employment, 21(1), 75-88. doi:10.1111/j.1468-005X.2006.00164.x.

Westlund, H., \& Bolton, R. (2003). Local social capital and entrepreneurship. Small Business Economics, 21(2), 77-113. doi:10.1023/a:1025024009072.

Vona, F., \& Consoli, D. (2015). Innovation and skill dynamics: a life-cycle approach. Industrial and Corporate Change, 24(6), 1393-1415. doi:10.1093/icc/dtu028.

Wood, P. (2005). A service-informed approach to regional innovation-or adaptation? The Service Industries Journal, 25(4), 429-445. doi:10.1080/02642060500092063.

Wright, M. (2011). Entrepreneurial mobilityIn D. D. Bergh, \& D. J. Ketchen (Eds.), Building Methodological Bridges (Research Methodology in Strategy and Management, Volume 6) (pp. 137-159)

Zander, I. (2004). The microfoundations of cluster stickinesswalking in the shoes of the entrepreneur. Journal of International Management, 10(2), 151-175. doi:10.1016/j. intman.2004.02.002. 